\title{
ANOTASI BIBLOGRAFI
}

\section{EFEKTIFITAS MEDIA PEMBELAJARAN BERBASIS MOBILE SMARTPHONE DAN PANDUAN PENGGUNAANNYA DALAM PROFESI KEGURUAN}

\author{
Oleh \\ Moh. Lutfi \\ Email: $1910111310015 @$ mhs.ulm.ac.id \\ Program Studi Pendidikan Sejarah Fakultas Keguruan dan Ilmu Pendidikan Universitas \\ Lambung Mangkurat \\ Banjarmasin
}

Susanto, H., \& Akmal , H. (2019). Media Pembelajaran Sejarah Era Teknologi Informasi (Konsep Dasar, Prinsip Aplikaf, dan Perancangannya).

Buku ini merupakan buku panduan untuk merancang media pembelajaran sejarah berbasis teknologi dengan menggunakan media mobile smartphone. Buku ini juga ditulis berdasarkan hasil penelitian dalam uji coba penggunaan media mobile smartphone dalam pengembangan media pembelajaran berbasis teknologi. Buku ini berisi dua bagian pembahasan. Bagian pertama berisi pendahuluan sebagai pengenalan tentang mata kuliah, rencana pembelajaran, petunjuk penggunaan dari buku ajar, dan bentuk evaluasi. Lalu, di bagian kedua merupakan isi yang ingin disampaikan dari buku ini. Di bagian ini terdapat tiga bab yang membahas hal yang berbeda, namun tetap terkait satu dengan yang lain. Di bab pertama membahas mengenai konsep dasar media pembelajaran, sumber belajar, alat peraga yang dapat digunakan, pengklasifikasian dan kriteria media pembelajaran sejarah, serta penggunaan gadget sebagai media pembelajaran sejarah. Lalu, di bab kedua membahas mengenai prinsip aplikasi pembuatan media, dengan sajian materi berupa analisis kebutuhan media, konseptual media, dan multimedia pembelajaran. Berlanjut ke bab tiga yang merupakan pembahasan akhir dari buku ini yang berfokus pada penjelasan mengenai perancangan media pembelajaran sejarah. 
Susanto, H., \& Akmal, H. (2018). Efektifitas Penggunaan Aplikasi Pembelajaran Berbasis Mobile Smartphone Sebagai Media Pengenalan Sejarah Lokal Masa Revolusi Fisik di Kalimantan Selatan Pada Siswa Sekolah Menengah Atas. HISTORIA: Jurnal Program Studi Pendidikan Sejarah, 6(2), 197-206.

Artikel ini merupakan sebuah penelitian yang mengkaji mengenai seberapa efektif penggunaan mobile smartphone sebagai penunjang dari media pembelajaran sejarah lokal revolusi fisik di Kalimantan Selatan. Dalam pendahuluan artikel ini menyoroti perkembangan media mobile smartphone yang memiliki banyak pengaruh di kalangan masyarakat. Berdasarkan latar belakang itulah artikel ini dibuat untuk melihat seberapa efektifkah jika pembelajaran sejarah diiringi dengan media teknologi. Artikel ini menyajikan penjelasan mengenai metode penelitian secara kualitatif dan teknis penelitian dengan subjek yang telah ditentukan untuk menjalankan penelitian. Berdasarkan artikel ini hasil yang diperoleh dari penelitian terbukti sukses dan efektif bahwa media pembelajaran menggunakan mobile smartphone dapat memberikan pemahaman dan peningkatan belajar dalam pengenalan sejarah lokal masa revolusi fisik di Kalimantan Selatan.

Susanto, H. (2020). Profesi Keguruan

Buku ini merupakan buku untuk bahan ajar profesi keguruan. Buku ini berisi dua bagian, di bagian pertama merupakan pendahuluan yang berisi penjelasan mengenai mata kuliah profesi keguruan. Kemudian, membahas rencana pembelajaran yang meliputi capaian pembelajaran; kemampuan akhir yang diharapkan; bahan kajian; metode pembelajaran; pengalaman belajar; kriteria, indikator, dan bobot pembelajaran; serta daftar referensi yang dapat digunakan untuk pendamping dari buku ajar ini. Di bagian pendahuluan ini juga disajikan petunjuk dari penggunaan buku ajar tersebut baik bagi siswa maupun peran dosen dalam pembelajaran, serta di bagian akhir dari pendahuluan terdapat bentuk-bentuk evaluasi yang dapat diterapkan oleh pendidik. Di bagian kedua dari buku ini membahas isi yang akan dijelaskan secara lebih mendalam dari buku ini. Pada bagian isi terdiri dari tiga bab, di bab pertama menjelaskan mengenai konsep dari profesi keguruan yang menjelaskan mengenai pengertian, kode etik, organisasi profesi keguruan, peran 
guru, serta hak dan kewajiban sebagai seorang guru. Lalu, pada bab kedua dibahas tentang penjelasan mendalam mengenai sikap profesional dari seorang guru dan penjelasan mengenai kompetensi guru yang meliputi kompetensi profesional guru, kompetensi pendagogik, kompetensi sosial, dan kompetensi kepribadian. Selanjutnya, di bab ketiga akan dibahas mengenai pengembangan dari profesi guru yang akan dijelaskan dari pengembangan aktivitas instruksional, pengembangan jenjang karir, dan pengembangan aspek keprofesian. Buku ini ditujukan bagi para mahasiswa untuk memahami tentang profesi keguruan, buku ini cocok menjadi sebuah rujukan bagi para mahasiswa yang ingin mempelajari profesi keguruan dari awal.

\section{Simpulan Anotasi Bibliografi}

Teknologi terus berkembang semakin pesat dari tahun ke tahun. Keefisienan dan efektifitas merupakan hal yang ditawarkan oleh perkembangan teknologi masa kini. Kemudahan dalam menjangkau teknologi juga menjadi alasan mengapa kemajuan pesat dari teknologi terus terjadi. Kehidupan serta gaya hidup manusia sekarang ini agaknya tidak bisa terlepas dari penggunaan teknologi sebagai penunjang kebutuhan hidup manusia. Teknologi seakan sudah merambah segala bidang kehidupan yang ada, tidak terkecuali dalam bidang pendidikan.

Penggunaan teknologi dalam bidang pendidikan di Indonesia sudah mulai menampakkan eksistensinya sedikit demi sedikit. Guru sebagai seorang fasilitator dan pengelola kelas juga seharusnya sudah dapat menguasai penggunaan media pembelajaran berbasis teknologi dalam pembelajarannya. Kehadiran teknologi dalam proses belajar mengajar tentunya akan memberikan suasana belajar yang berbeda, namun akan jadi lebih efektif dan efisien.

Mobile smartphone sebagai benda yang hampir dimiliki oleh setiap orang, tentunya dapat menjadi media pembelajaran yang mudah dan murah untuk melaksanakan pembelajaran. Oleh karena itu, guru sebagai pendidik harusnya juga dapat memanfaatkan potensi tersebut sebagai media mengajar yang menarik bagi siswa. Pembelajaran berbasis teknologi di masa sekarang tentunya akan sangat membantu baik guru maupun siswa dalam proses belajar mengajar. 